\title{
The Inner Work of Liberty \\ Cudworth on Desire and Attention
}

\author{
Matthew A. Leisinger
}

If there were any doubt about his position on human liberty, Ralph Cudworth puts it to rest in the very first sentence of $A$ Treatise of Freewill: ${ }^{1}$

We seem clearly to be led by the instincts of nature to think that there is something $\dot{\varepsilon} \varphi^{\prime} \dot{\eta} \mu \tilde{\mathrm{i}} v$ in nostra potestate, in our own power (though dependently upon God Almighty), and that we are not altogether passive in our actings, nor determined by inevitable necessity in whatsoever we do. $(4978,1 / \mathrm{TFW}, 155)^{2}$

Cudworth believes that the instincts of nature are correct. ${ }^{3}$ In his manuscript writings on freewill (most of which remain unpublished), he defends their suggestions by arguing against various forms of "fatalism" that would undermine human liberty by rendering our actions the necessary effects of causes beyond our control. For Cudworth, human liberty (the kind of liberty requisite for responsibility $)^{4}$ requires that our actions be in our own power ${ }^{5}$ in a robust sense that entails the power

\footnotetext{
${ }^{1}$ Cudworth belongs to a group of seventeenth-century philosophers often called the "Cambridge Platonists". For an introduction to Cambridge Platonism, see Hutton (2015, 136-159). The best general overview of Cudworth's philosophy remains Passmore (1951). The best overview of Cudworth's psychology in particular is Hutton (2017).

${ }^{2}$ Cudworth produced five manuscripts on the topic of freewill, British Library Additional Manuscripts 4978-4982, hereafter cited in the text by manuscript number followed by page number. Since 4982 is composed of three distinct manuscripts that have been bound together, I distinguish these sections as "4982 (I)", "4982 (II)", and "4982 (III)", followed by page number (using continuous pagination). While most of the manuscripts remain unpublished, 4978 was published in 1838 as $A$ Treatise of Freewill and republished in 1996 as “A Treatise of Freewill”, in $A$ Treatise Concerning Eternal and Immutable Morality: With A Treatise of Freewill, ed. Sarah Hutton, hereafter cited in the text as "TFW" followed by page number. Additionally, the final twelve pages of 4981 were published in 1997 as "Ralph Cudworth Additional Manuscript $\mathrm{N}^{\circ} 4981$ (On the Nature of Liberum Arbitrium): Summary PP. 1-12", in The Cambridge Platonists in Philosophical Context: Politics, Metaphysics and Religion, ed. G. A. J. Rogers, J. M. Vienne, and Y. C. Zarka, hereafter cited in the text as "Summary" followed by page number. When quoting published portions of the manuscripts, I follow the published versions in spelling and capitalization and provide references both to the published versions and to the originals. When quoting unpublished manuscripts, I have modernized Cudworth's spelling and capitalization and I have deleted crossed-out text. The composition history of the manuscripts remains a matter of speculation. The most up-to-date analysis is Burden (2019), but see also Carter (2011, 161-168) and Passmore (1951,107-113). As Cudworth's views seem to remain relatively stable across the manuscripts, I treat each as prima facie authoritative.

${ }^{3}$ Despite this opening appeal, Cudworth does not take the instincts of nature to be infallible but seeks to confirm their suggestions through argument. See Jaffro $(2009,651-653)$ on the methodology of this "phenomenological argument".

${ }^{4}$ Cudworth distinguishes the kind of liberty necessary for responsibility from the state of "true liberty" (4978, 9093/TFW, 196-197) in which our actions would be necessarily determined by the good.

${ }^{5}$ I italicize "in our own power" to emphasize its status as a term of art in Cudworth's philosophical vocabulary.
} 
to do otherwise or alternative possibilities. ${ }^{6}$ According to Cudworth, our actions would not be in our own power if fatalism were true because we would lack the power to do otherwise.

Cudworth defends human liberty against a number of familiar opponents, including Thomas Hobbes and the Reformed theologians. I am going to suggest, however, that his own unorthodox views about desire may pose an equal threat. As we will see in $\$ 1$, Cudworth thinks that desire itself is not in our own power-we cannot help but desire as we do-from which he infers that, if desire necessarily determined our actions, then our actions likewise would not be in our own power. To save human liberty, therefore, Cudworth must deny that desire necessarily determines our actions. As we will see in $\$ 2$, however, Cudworth also maintains that we necessarily will the greater apparent good and that only desire is able fundamentally to distinguish good and evil, from which he infers that desire alone motivates our (voluntary) actions. It is but a short step to the disastrous conclusion that our (voluntary) actions, like our desires, are not in our own power. ${ }^{7}$ If we cannot help but desire as we do and desire alone motivates our actions, then it seems to follow that we cannot help but act as we do either.

Cudworth's solution, I will argue (in $₫ 3$ ), is to shift the locus of human liberty inward. While desire alone motivates our actions, Cudworth argues that our inward responses to desire, unlike those desires themselves, are in our own power. By directing attention differently in response to desire, for example, Cudworth maintains that we are able to influence how desire shapes our all-things-considered judgments of the greater good and, consequently, our volitions and actions. Our actions are in our own power, therefore, only because they are influenced by these inward responses to desire, attention among them, that Cudworth takes to be in our own power.

\footnotetext{
${ }^{6}$ Sellars $(2012,945-949)$ argues that Cudworth inherits this conception of what it is for an action to be in our own power from Alexander of Aphrodisias.

${ }^{7}$ Cudworth may concede that desire need not motivate our involuntary actions, but these actions are not in our own power either precisely because they are involuntary. I will leave this qualification implicit in what follows and focus exclusively on voluntary actions.
} 


\section{Desire and Liberty}

To see why Cudworth takes desire to threaten human liberty, we can begin with his response to Hobbes. In Hobbes's view, appetites and aversions are motions in the body that arise when we prospectively imagine future pleasures and pains, and deliberation consists in the succession of appetites and aversions that arise when an agent successively imagines the possible positive and negative consequences of some action. An agent's will, for Hobbes, is simply the last appetite or aversion in such a succession (EW 3, 48). ${ }^{8}$ Given this conception of the will, Hobbes argues that an agent is free just in case "he is able to do, is not bindered to do what he has a will to" (EW 3, 196-197). In other words, human liberty is nothing more than the ability to act upon the last appetite or aversion in deliberation.

Cudworth finds this position implausible. He writes, for example, that "they adulterate the notion of freewill and liberty who affirm the meaning of it to be only this[,] that a man hath liberty to do what he will in such things as his power extends to, but that he hath not liberty to determine his will", as if "no rational being hath any more liberty than the fire hath of burning" (4982 (III), 118). ${ }^{9}$ It is worth pausing, however, to consider what exactly Cudworth finds objectionable in Hobbes's account.

Cudworth agrees with Hobbes on at least one point. He quotes a passage from Hobbes's De Homine with begrudging approval, conceding that "concerning these hormae, appetites and passions that in a late book de homine may in some sense be acknowledged to be true" $(4980,47$; see also 4979, 1 and 4981, 104/Summary, 219). Here is the passage to which Cudworth is referring:

$[\mathrm{N}]$ either our appetite nor our aversion causeth us to desire or shun this or that; that is, we do not desire because we will. For will itself is an appetite; and we do not shun something because we will not to do it, but because now appetite, then aversion, is generated by those

\footnotetext{
${ }^{8}$ References to Hobbes's English works are to Hobbes, The English Works of Thomas Hobbes of Malmesbury, ed. Sir Wiliam Molesworth, 11 vols, hereafter cited in the text as "EW" followed by volume and page number.

${ }^{9}$ For an excellent discussion of some of Cudworth's more specific arguments against Hobbes on liberty and necessity, see Esquisabel and Gaiada (2015, 171-177). See also Zarka (1997; 2012).
} 
things desired or shunned, and a preconception of future pleasure and displeasure necessarily follows from those same objects. What then: Do we desire food and the other necessities of nature because we will? Are hunger, thirst, and desires voluntary? When desiring, one can, in truth, be free to act, one cannot, however, be free to desire [...]. (Hobbes [1658] 1991, 45-46)

Hobbes claims that our desires (appetites and aversions) are neither voluntary nor free. Cudworth agrees on this point, writing that " $[\mathrm{b}] \mathrm{y}$ our own inward sense we are conscious to ourselves that these things [vi\% desires] invade us and obtrude themselves upon us and that they are so far from having any government of themselves that they are stubborn and contumacious, stiff and refractory things" $(4980,47)$. He goes on to explain that our desires "do necessarily arise upon occasion of the corporeal motions made upon external bodies" and therefore that "we are no[t] thought so much to be the cause of them ourselves as nature in us" $(4980,48)$. In other words, Cudworth concedes that desire itself is not in our own power. Since our desires are caused in us by forces of nature outside our control, it follows that we are not able to desire other than we do. ${ }^{10}$

Cudworth disagrees with Hobbes, however, about the proper conclusion to draw from this point of agreement. Hobbes argues that, because desire is involuntary, liberty must pertain only to outward action. I can be free to act as I will or desire, but I cannot be free to will or to desire. In Cudworth's view, however, this account fails to capture what is distinctive about human liberty. Indeed, Cudworth suggests that Hobbes's account might hold not of humans but of (non-rational) animals, writing that "deliberation" in brutes might indeed be nothing more than "a discord between narrow and short-sighted passions tugging against one another and alternately inclining the scale till the issue is at last determined either way by their respective prevalency" $(4980,7)$. In this case, animals would possess the Hobbesian liberty "to doe what they have an Appetite unto", but they would not possess the kind of liberty that is characteristic of human agents and requisite

${ }^{10}$ Compare Zarka $(1997,44)$. 
for responsibility—what Cudworth here calls "a Liberty or Power over their Appetites" (4981, 104/Summary, 220). On this hypothesis, animals would be nothing more than creatures of instinct, necessarily determined by their natural desires. Consequently, their actions would not be in their own power. ${ }^{11}$ Human liberty, Cudworth insists, requires something more.

Cudworth draws a different conclusion from the claim that desire is not in our own power. For Cudworth, the claims (1) that desire is not in our own power and (2) that desire necessarily determines our actions jointly entail (3) that our actions are not in our own power. In other words, if we cannot help but desire as we do, and if desire necessarily determines our actions, then it follows that we cannot help but act as we do either and therefore that we cannot be held responsible for our actions. Since Cudworth endorses (1) but denies (3), it follows that he must reject (2). This result sets the agenda for much of Cudworth's freewill manuscripts. In order to defend the claim that our actions are indeed in our own power, Cudworth must articulate an alternative account of human agency on which desire does not necessarily determine our actions.

This reaction to Hobbes is hardly unique to Cudworth. Cudworth's objections are similar, for example, to some of the worries that John Bramhall raises in his famous exchange with Hobbes, with which Cudworth was familiar. ${ }^{12}$ What makes Cudworth's response interesting is not his particular objections but the way in which he develops his own account in light of these objections. As we will see, Cudworth's unorthodox views about the nature of desire make it particularly challenging for him to maintain that desire does not necessarily determine our actions, leading him to a surprising explanation of what exactly is in our own power.

\section{Desire and Motivation}

If Cudworth is to argue that desire does not necessarily determine our actions, his first step must be to reject Hobbes's definition of the will as the last appetite or aversion in deliberation.

\footnotetext{
${ }^{11}$ Cudworth is not confident about this Hobbesian account of animal agency. In fact, Cudworth's views about animals seem to vary across the freewill manuscripts. I discuss these variations in Leisinger (2019).

12 See Chappell (1999) for the Hobbes-Bramhall correspondence. Burden (2019) suggests that Cudworth may have begun work on the freewill manuscripts shortly after acquiring the 1658 edition of the correspondence (Bramhall 1658).
} 
After all, if desire is not in our own power and the will is just a kind of desire, then it seems hard to avoid the conclusion that our actions likewise are not in our own power. While a complete explanation of Cudworth's alternative account of the will lies beyond the present scope, Cudworth speaks of "the will itself" as "something distinct from animal appetite" that "commands the action" (4979, 7). Accordingly, we may with minimal distortion of Cudworth's position understand the will as the soul's power to determine its actions in response to the motivations of desire. ${ }^{13}$

This redefinition, however, merely shifts the question. We must now ask not whether desire necessarily determines our actions but instead whether desire necessarily determines the will, which in turn determines our actions. Cudworth is an intellectualist about the will, holding that we necessarily will the greater apparent good. ${ }^{14}$ Indeed, Cudworth often suggests that the volition to perform some action may be identical to an agent's all-things-considered judgment of the greater good. ${ }^{15}$ So, if we want to know what determines the will—and, in particular, what role desire plays in its determination-we need to begin with Cudworth's account of how we distinguish good and evil. A brief detour through his moral epistemology is thus in order.

It was once standard to read Cudworth as a moral rationalist, holding that we grasp moral truths through the understanding in much the same way as we grasp the theoretical truths of mathematics or geometry. ${ }^{16}$ This interpretation would fit nicely with Cudworth's anti-Hobbesian ambitions. If the understanding distinguishes good and evil and we necessarily will the greater apparent good, then Cudworth could argue that desire does not necessarily determine our actions

\footnotetext{
${ }^{13}$ The distortion arises because Cudworth prefers to use the word "will" in a revisionary sense to refer not to a single power of the soul but to "the whole soul [...] acting upon itself and determining itself", suggesting that "that which is commonly called will" in fact "belongs to" the whole soul taken in this sense (4979, 6-7). These complications may be set aside for our purposes, but see $\$ 3$ for further discussion.

${ }^{14}$ For Cudworth's intellectualism, see 4980, 58-60, 288-289; 4981, 108-109/Summary, 225-226. Compare Irwin (2008, 241-249), who recognizes Cudworth's intellectualism but infers (mistakenly, in my view) that Cudworth's account of human liberty is compatible with determinism.

${ }^{15}$ For the identification of volition and judgment, see 4979, 6-7; 4980, 58-58*; 4981, 107/Summary, 222-223; 4982 (III), 82. There is a relatively large literature on Cudworth's discussion in $A$ Treatise of Freewill of the distinction between understanding and will (4978, 24-50/TFW, 166-178). See esp. Esquisabel and Gaiada (2015, 180-185), Irwin (2008, 241-243), and Pécharman (2014, 306-313).

${ }^{16}$ For the history of this interpretation, see Darwall (1995, 112n9). For a recent defence, see Gill (2006, 38-57; 2004). For the distinction between rationalism and sentimentalism in British moral epistemology, see Gill (2007).
} 
because we are able to determine ourselves to will what the understanding judges to be best, independent of desire.

J. A. Passmore $(1951,51-53)$ and Stephen Darwall $(1995,109-148)$ have raised decisive objections against this interpretation, however. In fact, even a cursory study of Cudworth's freewill manuscripts provides ample evidence that he is no moral rationalist. ${ }^{17}$ In one telling passage, Cudworth endorses rationalism about theoretical truths such as Notbing can at once be and not be or Equals added to equals make equals, which he takes to be innate to the human mind insofar as they are able to be grasped by the understanding alone $(4979,242) \cdot{ }^{18}$ He goes on, however, to reject a corresponding view about moral truths such as God is to be worshipped or Parents are to be honoured. He does not deny that such moral truths are able to be grasped by the understanding in some sense, but he suggests that they are unlike theoretical truths in that they originally "spring" not from the understanding but from a "vital source $[\ldots]$ within the soul itself" $(4979,242) .{ }^{19}$ He goes on to write that "all morality is to be resolved to some more simple and vital principle in the soul [...] something which is indeed above all intellectual ideas and rather touched and felt in us than seen" $(4979,243)$. Cudworth thus founds his moral epistemology not on the understanding but on some "vital principle".

For Cudworth, a vital principle is a principle of activity or motivation-literally, a principle of life. ${ }^{20}$ Cudworth distinguishes three vital principles in human beings: appetite, inferior reason,

\footnotetext{
17 Passmore and Darwall both base their objections in large part on the freewill manuscripts, and even Gill (2006, 278) acknowledges that they pose serious problems for his rationalist interpretation. Note, however, that the debate about Cudworth's alleged rationalism has focused primarily on the opening pages of 4982 (I). While these passages do weigh against the rationalist interpretation, they are hardly unique.

${ }^{18}$ Cudworth argues for nativism about theoretical truths in Book 4 of $A$ Treatise Concerning Eternal and Immutable Morality (Cudworth [1731] 1996, 73-152).

${ }^{19}$ Darwall $(1995,126-127)$ notes a similar passage from $A$ Treatise Concerning Eternal and Immutable Morality in which Cudworth likewise refrains from extending his rationalism from theoretical truths to moral truths (Cudworth [1731] 1996, 145).

${ }^{20}$ Cudworth's invocation of vital principles is part of a broader opposition to mechanism. Cudworth distinguishes generally between the mechanical activity of material bodies and the vital activity of immaterial spirits, and he argues in The True Intellectual System of the Universe that the motions of bodies can only be explained by appealing to the vital activity of "plastic natures" that animate the physical world (Cudworth 1678,146-174). There is little reason, however, to think that the vital principles of Cudworth's moral epistemology bear any more specific relation to these plastic natures (but cf. Breteau 1995b, 28). See Hutton (2017, 469-472, 480-483) on plastic natures in Cudworth's psychology.
} 
and superior reason. The first two, appetite and inferior reason, motivate us to pursue mere "animal delight" $\left(4980,58^{*} \mathrm{v}-59\right)^{21}$, which Cudworth seems to understand broadly as encompassing many qualitatively different kinds of pleasure, ranging from simple bodily pleasures to the more refined pleasures of honour or knowledge (4978, 41-42/TFW, 173-174). Consequently, Cudworth often groups appetite and inferior reason together as belonging to our lower, animal nature. They differ in that, whereas appetites "urge importunately towards their particular objects", inferior reason possesses "a larger comprehension of our own private utility than is in particular appetites and passions" $(4980,6)$. In other words, whereas appetite motivates us to pursue immediate gratification, inferior reason motivates us to pursue longer-term pleasures. ${ }^{22}$ By contrast, Cudworth maintains that the third vital principle, superior reason, is "the participation of a higher principle not only than particular appetites and passions but also than the whole animal life and reason of it" $(4980,10) \cdot{ }^{23}$ He explains that superior reason is, in fact, the human soul's finite participation in God's goodness, and therefore that it motivates us to pursue "another good of a different species[,] which is the good of honesty" (4980, 59v). Accordingly, Cudworth often refers to superior reason as the "dictate of honesty, or conscience" (4978, $25 / \mathrm{TFW}, 166){ }^{24}$

It is worth emphasizing that, despite their names, inferior and superior "reason" are indeed principles of motivation. Cudworth distinguishes inferior and superior reason from the understanding, writing that words such as "reason" or "understanding" are ambiguous, "being sometimes taken for dry logical reason, sometimes for the dictate of honesty which we call superior

\footnotetext{
${ }^{21}$ There are two pages in 4980 numbered " 58 ". "4980, 58*" designates the second of these two.

${ }^{22}$ It is unclear whether inferior reason motivates us to act in such a way as to satisfy as many of our appetites as possible in the long-term, or whether inferior reason instead motivates us to pursue a separate class of more durable, long-term pleasures.

${ }^{23}$ Because Cudworth groups appetite and inferior reason together, he sometimes says that the human soul possesses two vital principles - a lower, animal principle and a higher, divine principle — rather than three, as I have claimed (see e.g. 4979, 22 and 4980, 39). Cudworth often emphasizes, however, that appetite and inferior reason can come into conflict with one another in much the same way as the lower, animal principle can come into conflict with the higher, divine principle (see e.g. 4980, 5 and 182). As a result, I think that it is best to read Cudworth as distinguishing three principles, even if he often treats the two lower principles together in contrast with the third, higher principle. ${ }^{24}$ See Leech (2017) for further discussion of superior reason.
} 
reason[,] sometimes for a larger comprehension of our own utility that we call inferior reason" $(4979,176)$. Whereas the first of these is a purely theoretical faculty, inferior and superior reason differ from "dry rational and syllogizing understanding" in that they are "more simple inward and immediate instincts of nature", "not notional but vital things" $(4979,160)$. As a result, Cudworth holds that inferior reason and superior reason are principles of motivation similar in kind to appetite insofar each is able to incline an agent to action; just as appetite is "the lower animal inclination" (4979, 242), so too "superior and inferior reason" are "the inclination of honesty and that of private utility" $(4980,182) .^{25}$

In fact, Cudworth indicates that appetite, inferior reason, and superior reason are actually three principles of desire. Cudworth explains that "the first spring and principle of all deliberative action, can be no other than a constant, restless, uninterrupted desire, or love of good as such, and happiness" (4978, 40/TFW, 173). This single desire for good, in turn, gives rise to "two sorts, or species of [motions]" (4982 (I), 5), namely, the lower inclinations of appetite and inferior reason and the higher inclinations of superior reason. In this sense, Cudworth says that human beings have "a double spring of motion or desire in them[,] two several vital instincts that [...] suggest different ends of life and often clash with one another" (4979, 174-175). For Cudworth, therefore, inferior reason and superior reason are principles of desire similar in kind to appetite. ${ }^{26}$ One consequence of this position is that, like appetite, inferior reason and superior reason are not in our own power. Cudworth is quite clear on this point, attributing all three principles of desire equally to our "necessary nature" (see e.g. 4978, 44/TFW, 175; 4979, 164; 4980, 56). ${ }^{27}$ Even superior reason,

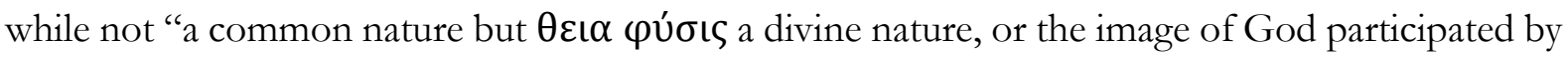

\footnotetext{
${ }^{25}$ I thus disagree with Jaffro $(2009,657)$, who seems to conceive of inferior and superior reason as two modes of deliberation rather than as two principles of motivation that prompt deliberation.

${ }^{26}$ But note that, while Cudworth does occasionally use the word "desire" in a general sense to encompass appetite, inferior reason, and superior reason, he more commonly uses "desire" in a narrow sense as synonymous with "appetite".

27 See also Breteau (1995a, 238-239; 1995b, 28-29), Hutton (2017, 478), and Pécharman (2014, 309).
} 
men", is "a living form, which man doth not actually produce but is passive to" that "is said to be formed not by us but in us" and therefore equally belongs to our necessary nature (4982 (I), 46).

Nonetheless, Cudworth's use of the word "reason" is no accident. Cudworth is a cognitivist about desire, holding that our desires not only motivate us to pursue various ends but also represent those ends as good or evil. As a result, Cudworth maintains that appetite, inferior reason, and superior reason are not only vital instincts or inclinations but also "vital sentiments of good and evil" $(4979,160)$. Cudworth argues for this cognitivist view by observing that the objects of desires always appear good:

For when the sensual appetite strongly inclines to anything there is a certain light of perception goeth along with the appetite, for that which we desire we always apprehend as good; in like manner, when the intellectual instinct [i.e. superior reason] inclines to honesty, that is not without a certain correspondent light, whereby we apprehend that to be good also [...]. (4982 (I), 37)

In Cudworth's view, the objects of desire always appear good because desire brings with it a certain "light" by which we "apprehend" those objects "as good". Elsewhere, Cudworth emphasizes the same duality by characterizing vital principles in the same breath both as "appetites or velleities" that motivate us to act in various ways and also as "lights knowledge or dictates concerning good and evil" (4982 (I), 12). For Cudworth, therefore, a desire is not merely an inclination towards some object but also a "vital sentiment" that represents or "dictates" its object to be good or evil. ${ }^{28}$ Cudworth thus rejects any sharp division between "reason" and "passion". This point is clearest in the case of superior reason. Cudworth criticizes Aristotle for calling "this vital instinct

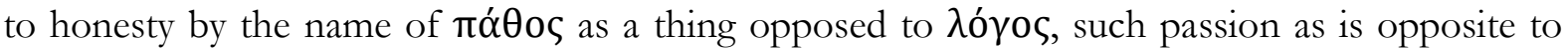
reason", arguing instead that "The first measure and rule of virtue is not logical reason, but a

\footnotetext{
${ }^{28}$ Cudworth thus espouses a kind of proto-sentimentalism. For further discussion, see Passmore (1951, 51-53), Darwall (1995, 109-148), and Leech (2017, 957-958). For Cudworth's influence on eighteenth-century sentimentalism, see Passmore (1951, 90-106), Gill (2010), and Hutton (2012).
} 
certain vital instinct $[\ldots]$ that is better than reason but is often called by that name" $(4979,218$; see also 4980, 292). For Cudworth, superior reason is in fact a higher form of reason (as compared with mere theoretical understanding) that represents its objects as good or evil. Something similar is true of inferior reason, "the dictate of private utility". Even appetite represents its objects as good or evil in some sense, even if it often does so mistakenly or irrationally. ${ }^{29}$

This cognitivism about desire helps to illuminate Cudworth's moral epistemology. Cudworth maintains that only vital principles are able to distinguish good and evil, at least fundamentally: "The first principle by which good and evil are distinguished is vital and not notional" (4982 (I), 9). Cudworth concedes that the understanding may play some role, perhaps by applying rational principles derived from desire (such as God is to be worshipped or Parents are to be honoured), but he denies that these principles are fundamental:

The speculative understanding alone by itself wanted principles to discern them [vi\%: good and evil] and judge them by. It is here but like the moon which shines with a borrowed and derivative light. (4982 (I), 9)

Since Cudworth distinguishes three different vital principles in human beings, the vital principle particularly relevant to his moral epistemology is superior reason, by which we distinguish moral good and evil in particular (as opposed to the non-moral good and evil of pleasure and pain). So, when Cudworth writes (in a passage quoted earlier) that "all morality is to be resolved to some more simple and vital principle in the soul [...] something which is indeed above all intellectual ideas and rather touched and felt in us than seen" $(4979,243)$, he is proposing to found his moral knowledge upon superior reason.

We can now return to Cudworth's anti-Hobbesian ambitions. Cudworth's goal is to argue that desire does not necessarily determine our actions. Since he holds that we necessarily will the

\footnotetext{
${ }^{29}$ Since Cudworth holds that even appetite represents its objects as good or evil, it follows that desire in general is not an infallible guide to good and evil. Indeed, even superior reason can surely be mistaken at least in cases of ignorance.
} 
greater apparent good, he could argue - if he were a moral rationalist—-that desire does not necessarily determine our actions because we are able to use the understanding to discern the greater good. Cudworth is not a moral rationalist, however. For Cudworth, only vital principles of desire are able fundamentally to distinguish good and evil. This rejection of moral rationalism threatens to undermine Cudworth's response to Hobbes. If only desire is able fundamentally to distinguish good and evil and we necessarily will the greater apparent good, then it seems to follow that, at least at bottom, desire alone motivates our actions.

Cudworth acknowledges this consequence of his view. He argues that "the first ends[,] which are indeed the beginnings of all motion[,] are not sought for, invented and elected by us, but as was before hinted are obtruded upon us and may be said in a sense to proceed from nature's activity in us" (4982, (I), 8). This is true, he writes, both in "the sphere of this animal life", where the ends of action arise from "self-desire" or "natural instinct", and also in the "life which is called divine", where the ends of action are dictated by the "inward simple divine principle" of superior reason, which "moves all that is in the virtuous life" (4982 (I), 8). In other words, whenever an agent wills to perform some action, regardless of the kind of end that she wills to pursue, Cudworth claims that her action is motivated fundamentally by desire-either by a lower, animal desire (appetite or inferior reason) or by a higher, divine desire (superior reason). As before, Cudworth concedes that the understanding may play some role, but he insists that this role is merely derivative, observing that "dry ratiocination [...] could not set itself awork nor make its own wheels move unless it were excited spirited enlivened and awakened by something else" (4982 (I), 8). As a result, while the understanding can function instrumentally to seek out the means for achieving our ends, Cudworth insists that those ends themselves must proceed fundamentally from desire. Cudworth's view, therefore, is that desire alone fundamentally motivates all of our actions.

It is but a short step from this conclusion to the further claim that desire necessarily determines our actions and, therefore, that our actions are not in our own power. After all, as we have seen, Cudworth holds that desire itself is not in our own power-we cannot desire other than we do. 
And, since Cudworth maintains that only desire can distinguish good and evil and that we necessarily will the greater apparent good, he also holds that only desire can motivate action. So, if only desire can motivate action and we cannot desire other than we do, then it seems to follow that we cannot act other than we do either. ${ }^{30}$ Our actions, it seems, are not in our own power. Cudworth's unorthodox views about desire, combined with his intellectualism about the will, thus threaten to undermine his defence of human liberty.

\section{Desire and Attention}

Cudworth confronts this challenge head-on: "But for all this though it be granted to be impossible for any being to will or do anything without respect of some good in it [...] yet it doth not therefore follow that motives and reasons of good necessarily coming upon us do necessarily determine all volitions and actions" (4980, 238v). His reasoning is worth quoting at length:

But the mistake of this argument [is] this[,] that it supposes all perceptive beings to be merely passive to appearances of good, reasons and motives of actions, whereas the case is otherwise, for as we are in some sense passive to nature in reasons, motives and appearances of good and these have a necessary force upon us, so we are also active upon the same, and such things have more or less force with us, accordingly as we do actively exert ourselves more or less upon them[.] The same reasons propounded will not necessarily have the same force with several different persons, nor with the same persons at several times, but as they do more or less intend themselves in consideration of them or attend more to this or to that, so will this or that be more prevalent with them. [...] Nature goes but half-way and the other half is something $\dot{\varepsilon} \varphi^{\prime} \dot{\eta} \mu \tilde{v} v$ or in our own power which we variously add of ourselves[.] (4980, 238; see also 4978, 53-54/TFW, 179-180)

\footnotetext{
30 This is not to say that desire is the only factor not in our own power that influences our actions. Cudworth often underscores habit, for example, as another such factor (see e.g. 4980, 61). Likewise, Cudworth recognizes that external circumstances also play a significant role $(4980,141)$. We can set aside these complications for present purposes, however.
} 
Since desire is not in our own power and desire alone is able to distinguish good and evil, Cudworth concedes that "we are in some sense passive to nature" with respect to the representations or "appearances" of good originating in desire. He denies, however, that we are entirely passive to these appearances. Instead, he argues that there is something "in our own power which we variously add of ourselves". More specifically, he says that we are able to "intend" ourselves "more or less" in "consideration" of those appearances of good that nature offers to us, or to "attend more to this or to that". In other words, while the desires by which we originally distinguish good and evil are not in our own power, the way in which we respond to these desires is indeed in our own power. Desire does not necessarily determine our actions because, as Cudworth puts it, "Nature goes but half-way": desire alone distinguishes good and evil, but our judgments, volitions, and actions may nonetheless differ depending on how we respond to desire.

A complete explanation of this proposal would take us rather deep into Cudworth's metaphysics of the soul. Briefly, however, Cudworth distinguishes two "stories or gradations and regions" within the soul $(4980,1)$. He illustrates this distinction with the image of a line: whereas the lower region "may be resembled to a straight line that is always running outwards and forwards without any flex or turning in upon itself", the higher region is like "a reflected line or circle it being a certain life that doth as it were return into rebound and reach upon itself' $(4980,48)$. Cudworth thus characterizes the higher region of the soul as "the whole soul redoubled upon itself" $(4980,1)$ and, in $A$ Treatise of Freewill, refers to the higher region as the "hegemonicon" or "the soul as comprehending itself" $(4978,51 / \mathrm{TFW}, 178) \cdot{ }^{31}$ Now, when the soul reflects upon its desires (which Cudworth locates in the lower region), Cudworth says that it is able to respond to these desires by engaging in a range of different activities. He lists many such activities, writing not only of "attention" and "consideration" but also for example of "girding up the loins of the mind", "mustering up all the forces of the soul to resist the assaults of temptations", and so on $(4980,85)$.

\footnotetext{
${ }^{31}$ For further discussion of the hegemonicon, see Breteau (1995a, 339-341; 1995b, 29), Hengsterman (2019), Hutton (2017, 479-483), Pécharman (2014, 308-313), and Zarka (1997, 45; 2012, 71-72).
} 
All of these various activities have at least two things in common: first, Cudworth takes each of them to be in our own power, second, they all have some influence on our judgments of the greater good. Given these commonalities, Cudworth says that the power to engage in all of these activities may be grouped together and "called by this general name the soul's self-intending and selfexerting power" (4979, 29), which he elsewhere identifies with the power of "freewill". ${ }^{32}$

Much more could be said about Cudworth's metaphysics of the soul, his account of freewill, and the crucial claim that the soul's reflective responses to desire are in its own power. In what remains, however, I want to examine Cudworth's proposal more concretely by focusing on what he says about one of these responses in particular: attention.

Suppose that an agent is choosing between A and B. Cudworth's intellectualism dictates that the agent will pursue whichever of these she judges to be best. Since Cudworth holds that only desire can distinguish good and evil, it follows that this judgment will be determined in large part by her desires. As we have seen, however, Cudworth distinguishes three principles of desire in human beings: appetite, inferior reason, and superior reason. It might turn out, therefore, that one principle of desire (say, appetite) represents A as good and B as evil while another principle of desire (say, superior reason) represents B as good and A as evil. In order to choose between A and $\mathrm{B}$, therefore, the agent must somehow adjudicate between these conflicting representations in order to arrive at an all-things-considered judgment of the greater good. One way of adjudicating such conflicts, Cudworth suggests, is by attending to one principle of desire and its representations of good and evil rather than another. As a result, the agent's judgment is determined not only by desire but also by the her own inward response to desire-in this case, the act of attention.

In fact, Cudworth distinguishes at least three ways in which attention can influence judgment. First, Cudworth observes that, since almost all goods contain some mixture of evil (and

\footnotetext{
${ }^{32}$ For Cudworth on freewill, see Breteau (1995a) and Hengstermann (2019). Note that we ought not to identify the hegemonicon and the power of freewill. Whereas the hegemonicon itself is "the soul as comprehending itself", Cudworth writes that the hegemonicon "[has] a power of intending or exerting itself" (4978, 51/TFW, 178). Freewill, therefore, is a power that belongs to the hegemonicon. For further discussion, see Hutton $(2017,480)$, who suggests conceiving of the hegemonicon as a "super-power" that itself comprises a number of more specific powers.
} 
vice versa), "it comes to pass that accordingly as the soul doth more or less fix its attention upon the good or evil of any of them it may either embrace or reject [them]" $(4979,16)$. In our example, if the agent attends to the good in $\mathrm{A}$ and the evil in $\mathrm{B}$, then she will be more likely to judge that $\mathrm{A}$ is best; by contrast, if she attends instead to the good in B and the evil in A, then she will be more likely to judge that B is best. Cudworth makes much the same point elsewhere, writing that "The same motives and reasons propounded have not always the same force and efficacy upon different persons, nor yet upon the same persons, neither at several times, but more or less as they are differently apprehended, or more or less attended to, pondered or considered" $(4978,54 / \mathrm{TFW}$, 179-180; see also 4980, 184 and 4981, 111v/Summary, 226n15). As a result, by directing attention towards different objects or towards different features of the same object, an agent may influence her all-things-considered judgment of the greater good by causing different representations of good or evil to weigh more heavily in that judgment.

Second, Cudworth notes that we sometimes choose the lesser of two goods as a result of "attending to some appearance of good in one of them without taking notice of the evils attending it" (4978, 52/TFW, 179). In our example, the agent might choose A instead of B not because she fails to attend to the representation of evil in A but because her desires fail to represent A as evil in the first place. By attending more carefully to A, the agent may come to discover new, normatively relevant features of A that subsequently effect a change in her desires, which thereby come to represent A as evil. If the agent realizes, for example, that the pleasure of A will actually be accompanied by some previously unrecognized pain, one consequence of this realization may be that appetite comes to represent A not as good but as evil. As a result, attention can influence an agent's all-things-considered judgment of the greater good not only by causing some representations of good to weigh more heavily in that judgment but also by discovering new facts about the situation that modify what her desires represent to be good in the first place.

Third, Cudworth often speaks not only of "attention" but of "self-attention", explaining that the soul may "awaken itself [...] to attain to a constant presence of mind[,] more deeply, 
inwardly and profoundly to reflect upon itself and listen to the inward dictates of its own mind" (4979, 24). The suggestion seems to be that we can respond to desire not only by paying attention to the objects of our desires but also by paying attention to our desires themselves. He elaborates elsewhere:

[T] hough there be different vital congruities in us which cause a great distraction, the one being that of honesty the other selfish animality pleasure and utility, the latter of which is not only more boisterous and violent than the former $[\ldots]$ but also more meretriciously flattering; yet the other whenever we closely attend to it we see that it hath the awful stamp of majesty and divinity upon it $[\ldots]$ though the other one be more bewitching and flexanimous, yet this other is more magisterial and commanding according to internal sense. They differ in us [... ] as law and force[,] the one seems to have right and equity of its side, the other an overbearing force, an irrational urgency, a dark impetuosity [...] And yet besides the vis and force it doth not want something of Suada ${ }^{33}$ too, sugared blandishments melting insinuations twining umbrages mellifluous and honey-dropping language, but that all which when it is heedfully attended to appears plainly suspicable of falsehood treachery and deceit. $(4979,166)$

Cudworth observes that different kinds of desires have different felt characteristics. Whereas the desires of superior reason appear to possess a rightful authority, those of appetite are at once overbearingly violent and deceptively sweet; whereas appetite by turns impels and seduces, superior reason motivates with the force of command. According to Cudworth, attention enables us to see these different kinds of desires for what they really are. When we "heedfully attend" to our baser appetites, we are able recognize their "treachery and deceit". By contrast, when we attend to the desires of superior reason, we find them marked with "the awful stamp of majesty and

\footnotetext{
33 The entry "Suada, n." in the Oxford English Dictionary reads: "The Roman goddess of persuasion; hence = persuasiveness, persuasive eloquence." Cudworth's point is that the "vital congruity" under discussion here (namely, appetite) does not merely compel action by "force" but also has a certain persuasiveness.
} 
divinity". ${ }^{34}$ The implication, it seems, is that we can influence our judgments of the greater good not only by attending to the objects of our desires but also through a kind of critical self-scrutiny in which we attend to our motives for pursuing those objects. In our example, if the agent attends not merely to A and B themselves but also to her desires for A and B, she may realize that the desire for $\mathrm{A}$ is a mere appetite while the desire for $\mathrm{B}$ is an authoritative dictate of superior reason. This realization, Cudworth implies, may itself influence the agent's all-things-considered judgment of the greater good.

The direction of attention is only one way in which Cudworth thinks that we are able to influence our judgments of the greater good in response to desire. Nonetheless, I think that Cudworth's discussion of attention is representative of a more general strategy. While all motivation begins with desire, which originally distinguishes good and evil, the judgments of the greater good that determine our volitions and actions depend not only on desire itself but also on our inward responses to desire-including, as we have seen, the direction of attention. Crucially, Cudworth maintains that these inwards responses to desire are in our own power. Unfortunately, Cudworth's argument for this crucial claim lies beyond the scope of this paper. Granting this claim, however, Cudworth concludes that our judgments, volitions, and actions are in our own power as well. Therefore, while Cudworth concedes that we cannot desire other than we do, he insists that we can indeed respond to desire other than we do, from which it follows that we can judge, will, and act other than we do as well.

\section{Conclusion}

Cudworth sets the bar for human liberty exceedingly high. He insists that genuine libertythe kind of liberty needed for responsibility_-demands that our actions be in our own power in a robust sense that entails the power to do otherwise. The trouble, from Cudworth's perspective, is

\footnotetext{
${ }^{34}$ Cudworth makes a similar observation when he says that we are "conscious of the several congruities in the soul, higher and lower, that of particular animal appetites of inferior reason and of the tò $\theta \varepsilon i ́ o v$ the divine principle in us as also of the superiority of these to one another" $(4980,51 ;$ my italics).
} 
that so much of human life depends on forces outside of our control. Our actions are determined by our volitions and our volitions are determined by the appearances of good and the appearances of good are determined by desires that nature springs upon us. Prima facie, it is hard to see where in this chain of causes genuine liberty is to get a foothold.

Cudworth's solution is to turn inwards. While Cudworth concedes that desire alone motivates our actions and that desire is not in our own power, he argues that our actions are determined not only by desire but also by our inward responses to desire, which are indeed in our own power. I can be held responsible for acting wrongly only because I could have, for example, paid closer attention to the dictate of superior reason, in which case I might have formed a more accurate judgment of the greater good and, consequently, might have acted otherwise. Cudworth concludes that we have the power to do otherwise because, while we cannot desire other than we do, we can respond to desire other than we do. ${ }^{35}$

\section{Bibliography}

Bramhall, John. 1658. Castigations of Mr. Hobbes his last animadversions, in the case concerning Liberty, and Universal Necessity. London: Printed by E. T. for J. Crook.

Breteau, Jean-Louis. 1995a. “«Un Grand Espace pour la Liberté? » : Le Dilemme du Libre Arbitre dans la Pensée de Ralph Cudworth." Archives de Philosophie 58 (3): 421-441.

Breteau, Jean-Louis. 1995b. "Introduction.” In Traité de morale et Traité du libre arbitre, edited by JeanLouis Breteau, 1-33. Paris: Presses Universitaires de France.

Burden, Mark. 2019. "Ralph Cudworth’s Freewill Manuscripts: A Roadmap to Dating and Analysis." The Cambridge Platonist Research Group, June 9. Accessed July 14, 2019. https://cprg.hypotheses.org/815

\footnotetext{
${ }^{35}$ I am grateful to Ruth Boeker for inviting me to present this paper at a workshop on agency in early modern philosophy held at University College Dublin in September 2018. I would like to thank the participants at that workshop, two anonymous referees for this journal, and Marleen Rozemond for their feedback.
} 
Carter, Benjamin. 2011. 'The Little Commonwealth of Man': The Trinitarian Origins of the Ethical and Political Philosophy of Ralph Cudworth. Leuven: Peeters.

Chappell, Vere, ed. 1999. Hobbes and Bramball on Liberty and Necessity. Cambridge: Cambridge University Press.

Cudworth, Ralph. Manuscripts on freewill. British Library Additional Manuscripts 4978-4982.

Cudworth, Ralph. 1678. The True Intellectual System of the Universe: The First Part; Wherein, All the Reason and Philosophy of Atheism is Confuted; and its Impossibility Demonstrated. London: Richard Royston.

Cudworth, Ralph. [1731] 1996. "A Treatise Concerning Eternal and Immutable Morality.” In $A$ Treatise Concerning Eternal and Immutable Morality: With A Treatise of Freewill, edited by Sarah Hutton, 1-152. Cambridge: Cambridge University Press.

Cudworth, Ralph. [1838] 1996. "A Treatise of Freewill." In A Treatise Concerning Eternal and Immutable Morality: With A Treatise of Freewill, edited by Sarah Hutton, 153-209. Cambridge: Cambridge University Press.

Cudworth, Ralph. 1997. "Ralph Cudworth Additional Manuscript $\mathrm{N}^{\circ} 4981$ (On the Nature of Liberum Arbitrium): Summary PP. 1-12." In The Cambridge Platonists in Philosophical Context: Politics, Metaphysics and Religion, edited by G. A. J. Rogers, J. M. Vienne, and Y. C. Zarka, 216-231. Dordrecht: Kluwer Academic Publishers.

Darwall, Stephen. 1995. The British Moralists and the Internal 'Ought': 1640-1740. Cambridge: Cambridge University Press.

Esquisabel, Oscar M. and María Griselda Gaiada. 2015. "Le libre arbitre et « le paradoxe des facultés ». Suárez, Hobbes et Leibniz selon le jugement de Cudworth.” Studia Leibnitiana 47 (2): 162-185.

Gill, Michael B. 2004. "Rationalism, Sentimentalism, and Ralph Cudworth.” Hume Studies 30 (1): 149-182. doi:10.1353/hms.2011.0243. 
Gill, Michael B. 2006. The British Moralists on Human Nature and the Birth of Secular Ethics. Cambridge: Cambridge University Press.

Gill, Michael B. 2007. "Moral Rationalism vs. Moral Sentimentalism: Is Morality More Like Math or Beauty?” Philosophy Compass 2 (1): 16-30. doi:10.1111/j.1747-9991.2006.00052.x.

Gill, Michael B. 2010. "From Cambridge Platonism to Scottish Sentimentalism." The Journal of Scottish Philosophy 8 (1), 13-31. doi:10.3366/E1479665109000487.

Hengstermann, Christian. 2019. "Freedom as Holistic Hegemonikon Causality: Origenist Libertarianism in Ralph Cudworth's Treatise of Freewill." In Origen's Pbilosophy of Freedom in 17thCentury England, edited by Alfons Fürst. Münster: Aschendorff.

Hobbes, Thomas. [1658] 1991. "On Man.” In Man and Citizen, edited by Bernard Gert, 33-85. Indianapolis: Hackett.

Hobbes, Thomas. 1839-1845. The English Works of Thomas Hobbes of Malmesbury. Edited by William Molesworth. 11 volumes. London.

Hutton, Sarah. 2012. "From Cudworth to Hume: Cambridge Platonism and the Scottish Enlightenment." Canadian Journal of Philosophy 42 (sup1): 8-26. doi:10.1080/00455091.2012.981009.

Hutton, Sarah. 2015. British Philosophy in the Seventeenth Century. Oxford: Oxford University Press.

Hutton, Sarah. 2017. "Salving the phenomena of mind: energy, hegemonikon, and sympathy in Cudworth." British Journal for the History of Philosopby 25 (3): 465-486. doi:10.1080/09608788.2016.1185601.

Irwin, Terence. 2008. The Development of Ethics: A History and Critical Study: Volume II: From Suarez, to Rousseau. Oxford: Oxford University Press.

Jaffro, Laurent. 2009. "Liberté morale et causalité selon Ralph Cudworth.” Revue Philosophique de Louvain 107 (4): 647-673. doi:10.2143/RPL.107.4.2044679.

Leech, David. 2017. "Cudworth on superintellectual instinct as inclination to the good." British Journal for the History of Philosophy 25 (5): 954-970. doi:10.1080/09608788.2017.1330188. 
Leisinger, Matthew A. 2019. “Animals, Freewill, and Animal Freewill: A Development in Cudworth's Freewill Manuscripts." The Cambridge Platonist Research Group, June 23. Accessed July 14, 2019. https://cprg.hypotheses.org/830

Passmore, J. A. 1951. Ralph Cudworth: An Interpretation. Cambridge: Cambridge University Press.

Pécharman, Martine. 2014. "Cudworth on Self-Consciousness and the I Myself." Vivarium 52: 287-314. doi:10.1163/15685349-12341278.

Sellars, John. 2012. "Stoics against Stoics in Cudworth's A Treatise of Freewill." British Journal for the History of Philosophy 20 (5): 935-952. doi:10.1080/09608788.2012.718870.

Zarka, Yves Charles. 1997. “Critique de Hobbes et Fondement de la Morale chez Cudworth.” In The Cambridge Platonists in Philosophical Context: Politics, Metaphysics and Religion, edited by G. A. J. Rogers, J. M. Vienne, and Y. C. Zarka, 39-52. Dordrecht: Kluwer Academic Publishers

Zarka, Yves Charles. 2012. "Penser l'Action Libre: Cudworth contre Hobbes." In Liberté et Necessité chez Hobbes et ses Conteporains, edited by Yves Charles Zarka, 67-79. Paris: Vrin. 